\title{
Competition and yield performance in mixtures of oats and barley - nitrogen fertilization, density and proportion of the components
}

\author{
KARI JOKINEN \\ Department of Crop Husbandry, University of Helsinki, \\ SF 00710 Helsinki, Finland \\ Present address: \\ Kemira Oy, Espoo Research Centre, P.O. Box 44, SF 02271 Espoo, Finland
}

\begin{abstract}
Competition and yield performance in mixtures of barley and oats were evaluated from addition series experiments (three experiments) in 1983 and in 1984. Three doses of nitrogen fertilization ( $10 \mathrm{kgN} / \mathrm{ha}, 40 \mathrm{kgN} / \mathrm{ha}$ and $80 \mathrm{kgN} / \mathrm{ha}$ ) were applied. In the first year the components were Agneta barley and Veli oats and in 1984 in addition to the previous combination also Ida barley and Veli oats were included.

The competitive relationship between components was analysed by replacement series model and by regression analysis. The results showed that the dominant component according to the regression analysis was also dominant according to the indices of the replacement series model independently of density and proportion.

Barley was generally more competitive than oats. The dominance of barley usually increased with increasing nitrogen fertilization, especially in the mixture of Agneta and Veli. All the yield components of the barley plants increased with the decreasing proportion of barley in the mixture.

In 1983, some mixtures overyielded significantly $(\mathrm{p}<0.05)$. The relative yield total being usually greater than one indicated yield advantage. In 1984, oats suffered from insect damage and neither barley cultivar was able to compensate enough so no overyielding occurred. The relative yield total was lower than one and thus no yield advantage was achieved.
\end{abstract}

Index words: Competition, yield advantage, barley, oats, mixtures

\section{INTRODUCTION}

Interest has been paid to crop mixtures for two main reasons: an increase in yield brought about by the complementary habits of associated genotypes, and greater stability of yield over locations and seasons due to the ability of at least one genotype in the mixture to yield well in adverse conditions (TAYLOR 1978). Approximately $50 \%$ of the barley and oats grain produced in Ontario is from mixtures of the two components ( $300000 \mathrm{ha})$ 
(FEJER et al. 1982).

In several studies of barley-oats mixtures grown for feed, grain yield increases over the mean of the components in monoculture have been observed and even overyielding has occurred (Salminen 1945, Van Dobben 1953, Bebawi and NAylor 1978, TAYlor 1978, FEJER et al. 1982). Ontario provincial agricultural statistiscs show that mixed grain consistently outyielded pure stands as reported by FEJER et al. (1982). In trying to combine the two species so that there was less mutual competition at critical stages, SyME and BREMNER (1968) found that mixture yields did not exceed the better component and were usually similar to mid-component.

In most cases of mixtures of oats and barley the yield of the mixture is compared with the average of the yield of the two monocultures. A higher yield of the mixture is interpreted as an argument for mixed cropping. This indicates that the yield advantage of mixtures is not always completely assessed. This is because without oalculation of relative yield total the interpretations based on the ratio of actual and expected yields can be misleading, especially in cases where compensation occurs (WILley 1979). Compensation seems also to be the most common situation with mixtures of barley and oats, i.e. the competitive abilities of barley and oats differ (for example Salminen 1945, de Wit 1960, Syme and Bremner 1968, Fejer et al. 1982).

A mixture of species might more efficiently utilize the resources and therefore yield more than the pure stand. This may indicate that intraspecific competition is more severe than interspecific interference with growth. For these reasons mixtures might be expected to show a yield advantage (SPITTERS 1983). To achieve an accurate assessment of the relative strengths of intra- and interspecific competition in mixtures of barley and oats, these experiments were conducted.

In the experiments described here, replacement series (substitutive) (de WIT 1960, HARPER 1977, ConNOlly 1986) at three total plant densities of barley-oats mixtures and monocultures were used to assess the competitional relationship between species and the yield advantage of mixtures. The design is characterized by the term addition series (SPITTERS 1983).

Two approaches were used to analyse competition. The first approach was to use measures of competitive abilities and combining abilities of varieties based on the relative yield responses according to the de Wit model (de WrT 1960). The other approach is based upon linear regression with the reciprocal of average plant grain yield as the dependent variable and density as the independent variable. The reciprocal yield model was expanded for multiple genotypes by WRIGHT (1981) and SPITTERS (1983).

\section{MATERIALS AND METHODS}

The addition series field experiments were carried out in 1983 (one experiment) and in 1984 (two experiments) at the experimental farm of the University of Helsinki in Helsinki Viikki $\left(60^{\circ} 13^{\prime} \mathrm{N}, 25^{\circ} 00^{\prime} \mathrm{E}\right)$ with barley and oats sown separately and in mechanical mixtures. In 1984, the experiments situated side by side. In 1983, the soil was silty clay with pH 5.6 and in 1984 finer fine sand with $\mathrm{pH}$ 5.4 .

Experimental design and management. A split-split-plot design (nitrogen levels in main plots, total densities in subplots and genotypic composition of stand in subsubplots) was used with three blocks. The subplot size was $10 \mathrm{~m}^{2}$ $(1.25 \mathrm{~m} \mathrm{x} 8 \mathrm{~m})$ with rows spaced $12.5 \mathrm{~cm}$ apart. In 1983, the varieties were Agneta barley and Veli oats and in 1984, in addition to previous combination, also Ida barley and Veli oats were included. The general characters of the cultivars are described elsewhere (JOKINEN 1991 a).

The total densities in 1983 were 200,400 and 600 seeds $/ \mathrm{m}^{2}$ and in 1984200,500 and 800 seeds $/ \mathrm{m}^{2}$. The proportions based on plant numbers were $25 / 75,50 / 50$ and $75 / 25$. Granular NPK (N 2\%, P 8\%, K 12\%) (500 
$\mathrm{kg} / \mathrm{ha}$ ) combined with calcium ammonium nitrate $(\mathrm{CAN})(\mathrm{N} 27 \%$ ) was applied at the rate of nitrogen 10, 40 and $80 \mathrm{kgN} / \mathrm{ha}$. Sowing dates were 5 May in 1983 and 18 May in 1984. The crops were kept free of weeds by one application of the herbicide Actril S (2-3 liters/ha mixed with 300 liters of water) containing MCPA (235 g/l), dichlorprop (184 $\mathrm{g} / \mathrm{l})$, ioxynil (38 g/l) and bromoxynil (24 g/l) at the time of shoot emergence. At maturity the total area of each plot was harvested (10 August in 1983 and 6 September in 1984) and the grain yields were determined $(\mathrm{kg} / \mathrm{ha}$ at $15 \%$ moisture content).

Sampling and analyses. The number of plants in each plot were determined by counting the number of seedlings in four randomly selected 1-m-long rows/plot about three weeks after sowing before the start of tillering. Similarly the number of generative shoots in 1983 was determined after the complete ear emergence of the cultivars. The height of the stands was estimated visually as well as the emergence time of seedlings. Four weeks after sowing in 1984 samples were taken in three randomly selected 1-m-long rows/plot for determination of the total above ground dry matter of the plants.

From each mixture yield a $50 \mathrm{~g}$ sample was taken for determination of the seed yield of the barley and oats components. The separat- ed samples of each mixture as well as samples of each pure stand yield were used for determination of 1000 grain weights $(\mathrm{g})(3 \times 100$ seeds/sample) in 1983. The number of grains/head was calculated using the data of yield, number of generative shoots and 1000 grain weight.

Relative yield (RY) and relative yield total (RYT) were calculated according to the method of de Wit and van den Berg (1965). Competitive ratio (CR) was determined according to the method of WILEY and RAO (1980). The mean yield/area was calculated before computing the indices. Details of the calculations are described elsewhere (JOKINEN 1991 b)

A discussion of the use of hyperbolic yielddensity equations in various situations has been given elsewhere (WrIGHT 1981, SPITTERS 1983, Firbank and WatKINSON 1985, 1990, Connolly 1987, Roush et al. 1989). The method used here was described previously (JOKINEN $1991 \mathrm{c}$ ).

Data on the plant dry weights, the grain yields, 1000 grain weight and the number of generative shoots were subjected to analyses of variance for split-split-plot design (STEEL and TORrIE 1980). Mean separation was accomplished by Tukey's honestly significant difference test (HSD) $(\mathrm{P}=0.05)$ (STEEL and TORRIE 1980).

Table 1. The influence of nitrogen fertilization and proportion of oats in the stand on the phytomass accumulation (dry weight $\mathrm{mg} /$ plant) of Veli oats during the first month of growth in 1984 in two barley-oats experiments (Veli/Ida and Veli/Agneta). The analysis of variance is done separately for each experiment. Dry weight means in the average columns and in the average rows followed by the same letter are not significantly different at the 5\% level (HSD test).

\begin{tabular}{|c|c|c|c|c|c|c|c|c|}
\hline \multirow{3}{*}{$\begin{array}{l}\text { Proportion } \\
\text { Oats/barley }\end{array}$} & \multicolumn{8}{|c|}{ The component of oats in the mixture } \\
\hline & \multicolumn{4}{|c|}{$\begin{array}{c}\text { Ida barley } \\
\text { Nitrogen }(\mathrm{kgN} / \mathrm{ha})\end{array}$} & \multicolumn{4}{|c|}{$\begin{array}{c}\text { Agneta barley } \\
\text { Nitrogen }(\mathrm{kgN} / \mathrm{ha})\end{array}$} \\
\hline & 10 & 40 & 80 & Average & 10 & 40 & 80 & Average \\
\hline $100 / 0$ & 144 & 179 & 190 & $171 \mathrm{c}$ & 151 & 188 & 185 & $175 d$ \\
\hline $75 / 25$ & 134 & 167 & 173 & $158 \mathrm{bc}$ & 133 & 174 & 172 & $160 \mathrm{c}$ \\
\hline $50 / 50$ & 134 & 147 & 160 & $147 b$ & 125 & 140 & 146 & $137 \mathrm{~b}$ \\
\hline $25 / 75$ & 124 & 139 & 137 & $133 \mathrm{a}$ & 105 & 127 & 130 & $121 \mathrm{a}$ \\
\hline Average & $134 \mathrm{a}$ & $158 \mathrm{~b}$ & $165 b$ & 152 & $129 \mathrm{a}$ & $157 \mathrm{~b}$ & $158 \mathrm{~b}$ & 148 \\
\hline
\end{tabular}




\section{RESULTS}

\section{Vegetative development and lodging}

In both years the barley seedlings emerged first, about three days earlier than the oats. The first leaves of barley were larger than those of oats (data not given). The number of seedlings in each plot was about the same $(0.95-1.05)$ as expected (data not given).

The average phytomass of the oats was approximately the same in both experiments (Table 1). Both barley varieties were over twice heavier than the oats (Tables 1 and 2). The average phytomass of all the varieties decreased with increasing density (data not given). The seedlings of Agneta were heavier than those of Ida. Unlike the oats, the phytomass of the barley varieties increased with decreasing proportion of the species in the mixture. Both barley varieties were more competitive than the oats competitive ratio varying from 1.21 to 1.52 (data not given). The relative yield totals varied from 0.96 to 1.05 (data not given).

No lodging occurred in 1983. In 1984, the pure stands of barley at the highest density and the highest level of nitrogen fertilization were the most lodged (Table 3).

\section{Grain yields}

In 1983, the mean yield of the experiment of Veli oats and Agneta barley was $5446 \mathrm{~kg} / \mathrm{ha}$ (Table 4). The analysis of variance showed sig-

Table 2. The influence of nitrogen fertilization and proportion of barley in the stand on the phytomass accumulation (dry weight mg/plant) of Ida barley and Agneta barley during the first month of growth in 1984 in two barley-oats experiments (Veli/Ida and Veli/Agneta). The analysis of variance is done separately for each experiment. Dry weight means in the average columns and in the average rows followed by the same letter are not significantly different at the $5 \%$ level (HSD test).

\begin{tabular}{|c|c|c|c|c|c|c|c|c|}
\hline \multirow{2}{*}{$\begin{array}{l}\text { Proportion } \\
\text { Barley/Oats }\end{array}$} & \multicolumn{4}{|c|}{$\begin{array}{c}\text { Ida barley } \\
\text { Nitrogen }(\mathrm{kgN} / \mathrm{ha})\end{array}$} & \multicolumn{4}{|c|}{$\begin{array}{c}\text { Agneta barley } \\
\text { Nitrogen }(\mathrm{kgN} / \mathrm{ha})\end{array}$} \\
\hline & 10 & 40 & 80 & Average & 10 & 40 & 80 & Average \\
\hline $100 / 0$ & 271 & 348 & 353 & $324 a$ & 317 & 397 & 455 & $390 \mathrm{a}$ \\
\hline $75 / 25$ & 296 & 341 & 334 & $324 a$ & 336 & 431 & 453 & $407 b$ \\
\hline $50 / 50$ & 315 & 384 & 362 & $354 \mathrm{~b}$ & 353 & 445 & 476 & $425 c$ \\
\hline $25 / 75$ & 326 & 359 & 390 & $358 \mathrm{~b}$ & 364 & 490 & 466 & $440 \mathrm{~d}$ \\
\hline Average & $302 a$ & $358 \mathrm{~b}$ & $360 \mathrm{~b}$ & 340 & $343 \mathrm{a}$ & $441 b$ & $463 b$ & 416 \\
\hline
\end{tabular}

Table 3. Lodging of the stands ( $\%$ of area) in 1984. $(-=$ no lodging, $100=$ completely lodged, $\mathrm{Ag}=\mathrm{Agneta} / \mathrm{Veli}$, Id = Ida/Veli).

\begin{tabular}{|c|c|c|c|c|c|c|c|c|c|c|c|c|}
\hline \multirow{5}{*}{$\begin{array}{l}\text { Proportion } \\
\text { Oats/barley }\end{array}$} & \multicolumn{12}{|c|}{ Nitrogen fertilization $(\mathrm{kgN} / \mathrm{ha})$} \\
\hline & \multicolumn{6}{|c|}{$\begin{array}{c}40 \\
\text { Density (plants } / \mathrm{m}^{2} \text { ) }\end{array}$} & \multicolumn{6}{|c|}{$\begin{array}{c}80 \\
\text { Density (plants } / \mathrm{m}^{2} \text { ) }\end{array}$} \\
\hline & \multirow{2}{*}{\multicolumn{2}{|c|}{200}} & \multirow{2}{*}{\multicolumn{2}{|c|}{$\begin{array}{c}500 \\
\text { Stand }\end{array}$}} & \multirow{2}{*}{\multicolumn{2}{|c|}{800}} & \multirow{2}{*}{\multicolumn{2}{|c|}{200}} & \multirow{2}{*}{\multicolumn{2}{|c|}{$\begin{array}{c}500 \\
\text { Stand }\end{array}$}} & \multicolumn{2}{|c|}{800} \\
\hline & & & & & & & & & & & & \\
\hline & Id & $\mathrm{Ag}$ & Id & $\mathrm{Ag}$ & Id & $\mathrm{Ag}$ & Id & $\mathrm{Ag}$ & Id & $\mathrm{Ag}$ & Id & $\mathrm{Ag}$ \\
\hline $100 / 0$ & - & - & - & - & - & - & - & - & - & - & - & - \\
\hline $75 / 25$ & - & - & - & - & - & - & - & - & - & - & - & - \\
\hline $50 / 50$ & - & - & - & - & - & - & - & - & - & 10 & - & - \\
\hline $25 / 75$ & - & - & - & - & 10 & 20 & - & 47 & - & 33 & 18 & 77 \\
\hline $0 / 100$ & - & 3 & - & 22 & 32 & 52 & - & 47 & 33 & 83 & 83 & 93 \\
\hline
\end{tabular}


nificant $(\mathrm{p}<0.05)$ interaction between the nitrogen fertilization and the proportion of the components, and between the density and the proportion of the components. At the lowest level of nitrogen two out of three mixtures yielded significantly more (approximately 9\%) than the pure stands, i.e. the mixtures overyielded. At the highest density all the mixtures overyielded significantly (approximately 7\%). Comparison between the actual and expected yields of the mixtures (50:50) shows that all the mixtures were more productive than monocultures.

In 1984, the mean yield in both experiments was lower than in the previous year (Tables 5 and 6). This was due to the very low yield of oats because of frit fly (Oscinella frit) damage. In general, the grain yield of the stands increased with increasing proportion of barley in the mixture and no overyielding oc-

Table 4. The influence of nitrogen fertilization, density and the proportion of barley (Agneta) and oats (Veli) in the mixture on the grain yield $(\mathrm{kg} / \mathrm{ha})$ of the stands in 1983. A/E is the ratio of the actual and expected yield of the mixture of 50:50. Grain yield averages within each treatment (nitrogen fertilization, density and proportions) followed by the same letter are not significantly different at the $5 \%$ level (HSD test). Comparison between the grain yield averages of different proportions is done at different levels of nitrogen and density (interaction statistically significant).

\begin{tabular}{|c|c|c|c|c|c|}
\hline \multirow{2}{*}{$\begin{array}{l}\text { Proportion } \\
\text { Oats/barley }\end{array}$} & \multirow{2}{*}{$\begin{array}{c}\text { Density } \\
\text { (plants } / \mathrm{m}^{2} \text { ) }\end{array}$} & \multicolumn{4}{|c|}{ Nitrogen fertilization $(\mathrm{kgN} / \mathrm{ha})$} \\
\hline & & 10 & 40 & 80 & Average \\
\hline \multirow[t]{4}{*}{$100 / 0$} & 200 & 3941 & 4344 & 4383 & 4223 a \\
\hline & 400 & 4829 & 5332 & 5608 & 5256 a \\
\hline & 600 & 5138 & 5397 & 5973 & $5503 \mathrm{a}$ \\
\hline & Average & $4636 \mathrm{ab}$ & 5024 a & 5321 a & 4994 a \\
\hline \multirow[t]{4}{*}{$75 / 25$} & 200 & 4682 & 5044 & 5331 & $5022 \mathrm{~b}$ \\
\hline & 400 & 5237 & 5670 & 6093 & $5667 \mathrm{bc}$ \\
\hline & 600 & 5198 & 6130 & 6368 & $5899 \mathrm{~b}$ \\
\hline & Average & $5039 \mathrm{c}$ & $5614 \mathrm{~b}$ & $5931 \mathrm{~b}$ & $5528 \mathrm{bc}$ \\
\hline \multirow[t]{4}{*}{$50 / 50$} & 200 & 4576 & 5179 & 5494 & $5083 \mathrm{~b}$ \\
\hline & 400 & 5316 & 6009 & 6396 & $5907 \mathrm{c}$ \\
\hline & 600 & 5325 & 5690 & 6742 & 5919 b \\
\hline & Average & $5072 \mathrm{c}$ & $5626 \mathrm{~b}$ & $6211 \mathrm{bc}$ & $5636 \mathrm{c}$ \\
\hline \multirow[t]{4}{*}{$25 / 75$} & 200 & 4294 & 5313 & 5772 & $5126 \mathrm{~b}$ \\
\hline & 400 & 5068 & 5894 & 6582 & $5848 \mathrm{bc}$ \\
\hline & 600 & 5228 & 6048 & 6557 & $5944 \mathrm{~b}$ \\
\hline & Average & $4863 \mathrm{bc}$ & $5752 \mathrm{~b}$ & $6304 \mathrm{c}$ & $5640 \mathrm{c}$ \\
\hline \multirow[t]{4}{*}{$0 / 100$} & 200 & 4290 & 5585 & 5754 & $5210 \mathrm{~b}$ \\
\hline & 400 & 4676 & 5727 & 6274 & $5559 \mathrm{ab}$ \\
\hline & 600 & 4508 & 5891 & 6206 & $5535 \mathrm{a}$ \\
\hline & Average & 4491 a & $5734 \mathrm{~b}$ & $6078 \mathrm{bc}$ & $5434 \mathrm{~b}$ \\
\hline \multirow[t]{4}{*}{ Average } & 200 & 4357 & 5093 & 5347 & 4932 a \\
\hline & 400 & 5025 & 5726 & 6191 & $5647 \mathrm{~b}$ \\
\hline & 600 & 5079 & 5831 & 6369 & $5760 \mathrm{~b}$ \\
\hline & Average & 4820 a & $5550 \mathrm{~b}$ & 5969 b & 5446 \\
\hline \multirow[t]{4}{*}{$\mathrm{A} / \mathrm{E}$} & 200 & 111 & 104 & 108 & 107 \\
\hline & 400 & 118 & 109 & 108 & 109 \\
\hline & 600 & 110 & 101 & 111 & 107 \\
\hline & Average & 111 & 104 & 109 & 108 \\
\hline
\end{tabular}


curred. It is important to note that in 1984 in both experiments the actual yields of mixtures (50:50) were higher than expected in some cases (Tables 5 and 6).

\section{Relative yields (RY), relative yield totals (RYT) and competitive ratio (CR)}

In 1983, the relative yield of Veli oats was higher than expected only at the lowest level of nitrogen fertilization (Fig. 1). In 1984, the relative yield of oats was always lower than expected (Figs. 3 and 5). In both years the relative yields of barley were usually higher than expected (Figs. 1, 2 and 3).

In general, barley was more competitive than oats (CR>1) (Figs. 2, 4 and 6). Only in 1983 at the lowest level of nitrogen fertilization were oats as competitive as barley in some cases (Fig. 2). In 1984, Agneta was more com-

Table 5. The influence of nitrogen fertilization, density and the proportion of barley (Agneta) and oats (Veli) in the mixture on the grain yield $(\mathrm{kg} / \mathrm{ha})$ of the stands in $1984 . \mathrm{A} / \mathrm{E}$ is the ratio of the actual and expected yield of the mixture of 50:50. Grain yield averages within each treatment (nitrogen fertilization, density and proportions) followed by the same letter are not significantly different at the 5\% level (HSD test). Comparison between the grain yield means of different proportions is done at different levels of nitrogen and density (interaction statistically significant).

\begin{tabular}{|c|c|c|c|c|c|}
\hline \multirow{2}{*}{$\begin{array}{l}\text { Proportion } \\
\text { Oats/barley }\end{array}$} & \multirow{2}{*}{$\begin{array}{c}\text { Density } \\
\text { (plants } / \mathrm{m}^{2} \text { ) }\end{array}$} & \multicolumn{4}{|c|}{ Nitrogen fertilization (kgN/ha) } \\
\hline & & 10 & 40 & 80 & Average \\
\hline \multirow[t]{4}{*}{$100 / 0$} & 200 & 2762 & 2303 & 2748 & 2604 a \\
\hline & 500 & 2674 & 2444 & 2368 & 2495 a \\
\hline & 800 & 2852 & 2179 & 2817 & 2616 a \\
\hline & Average & 2763 a & 2309 a & 2644 a & 2572 a \\
\hline \multirow[t]{4}{*}{$75 / 25$} & 200 & 2288 & 3452 & 2751 & 2830 a \\
\hline & 500 & 3701 & 3368 & 3478 & $3516 \mathrm{~b}$ \\
\hline & 800 & 3215 & 3947 & 3693 & $3618 \mathrm{~b}$ \\
\hline & Average & 3068 a & $3589 \mathrm{~b}$ & $3307 \mathrm{~b}$ & $3321 \mathrm{~b}$ \\
\hline \multirow[t]{4}{*}{$50 / 50$} & 200 & 3476 & 4317 & 3987 & $3927 \mathrm{~b}$ \\
\hline & 500 & 4069 & 4628 & 4551 & $4416 \mathrm{c}$ \\
\hline & 800 & 3631 & 4758 & 5042 & $4477 \mathrm{c}$ \\
\hline & Average & $3725 \mathrm{~b}$ & $4568 c$ & $4527 \mathrm{c}$ & $4273 \mathrm{c}$ \\
\hline \multirow[t]{4}{*}{$25 / 75$} & 200 & 4446 & 4883 & 4440 & $4590 \mathrm{c}$ \\
\hline & 500 & 4832 & 5160 & 5506 & $5166 \mathrm{~d}$ \\
\hline & 800 & 5274 & 5797 & 5342 & $5471 \mathrm{~d}$ \\
\hline & Average & $4851 \mathrm{c}$ & $5280 \mathrm{~d}$ & $5096 \mathrm{c}$ & $5076 \mathrm{~d}$ \\
\hline \multirow[t]{4}{*}{$0 / 100$} & 200 & 5255 & 5856 & 5694 & $5602 \mathrm{~d}$ \\
\hline & 500 & 6095 & 6162 & 6228 & 6162 e \\
\hline & 800 & 5789 & 5841 & 5425 & $5685 \mathrm{~d}$ \\
\hline & Average & $5713 \mathrm{~d}$ & $5953 \mathrm{e}$ & $5782 \mathrm{~d}$ & $5816 \mathrm{e}$ \\
\hline \multirow[t]{4}{*}{ Average } & 200 & 3645 & 4162 & 3924 & 3911 a \\
\hline & 500 & 4274 & 4352 & 4426 & $4351 \mathrm{~b}$ \\
\hline & 800 & 4152 & 4504 & 4464 & $4373 \mathrm{~b}$ \\
\hline & Average & 4024 a & 4340 a & 4271 a & 4212 \\
\hline \multirow[t]{4}{*}{$\mathrm{A} / \mathrm{E}$} & 200 & 86 & 106 & 94 & 96 \\
\hline & 500 & 93 & 107 & 106 & 102 \\
\hline & 800 & 84 & 119 & 122 & 108 \\
\hline & Average & 88 & 111 & 107 & 102 \\
\hline
\end{tabular}



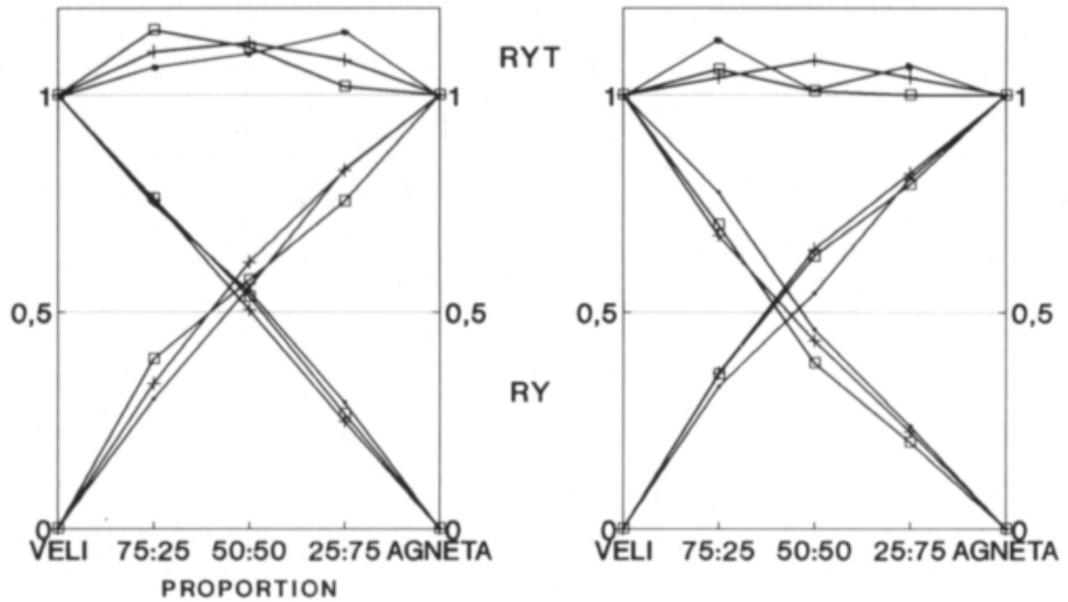

$80 \mathrm{kgN} / \mathrm{ha}$

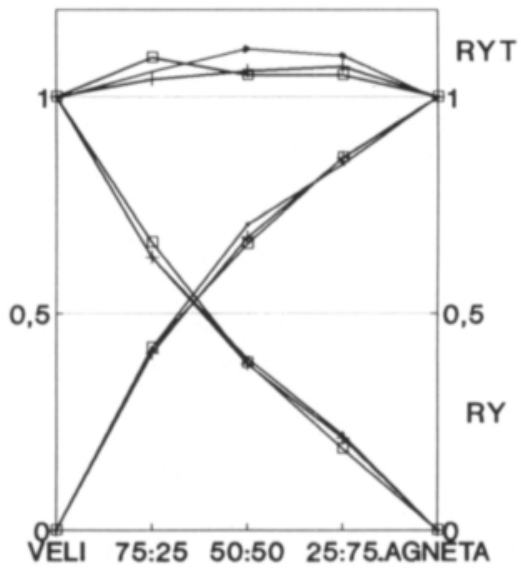

TOTAL DENSITY

$\rightarrow 200$ plants/m2

+400 plants/m2

- 600 plants/m2

RY

Figure 1. The influence of density (plants/ $\left.\mathrm{m}^{2}\right)$, nitrogen fertilization $(\mathrm{kg} \mathrm{N} / \mathrm{ha})$ and proportion of the components on the relative yields (RY) of Agneta barley and Veli oats, and on the relative yield totals (RYT) of the mixtures in 1983.

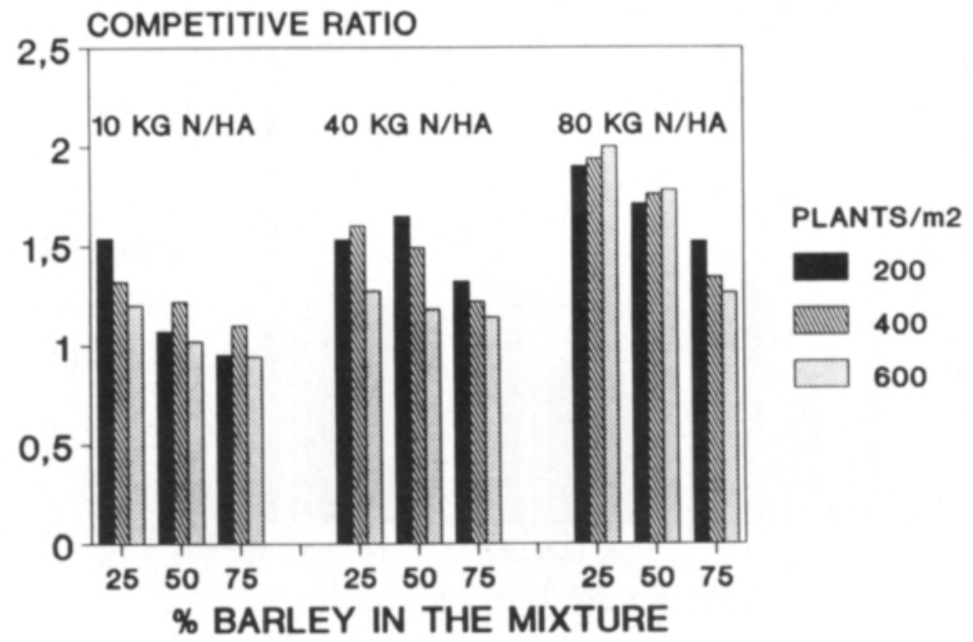

Figure 2. The influence of density $\left(\right.$ plants $\left./ \mathrm{m}^{2}\right)$, nitrogen fertilization $(\mathrm{kg} \mathrm{N} / \mathrm{ha})$ and proportion of barley on the competitive ratio (CR) of Agneta barley over Veli oats in 1983. 
$10 \mathrm{kgN} / \mathrm{ha}$

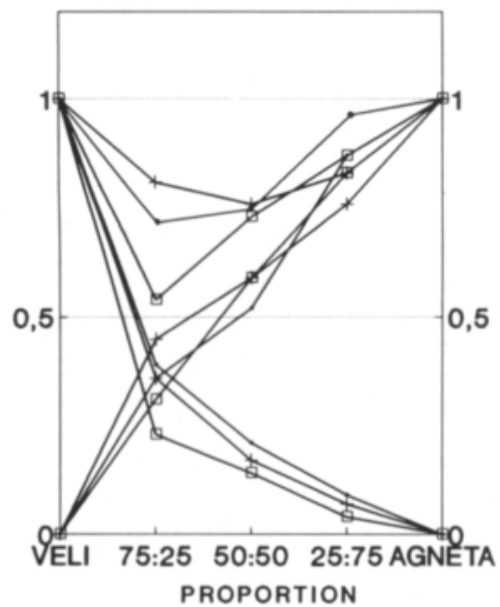

$80 \mathrm{kgN} / \mathrm{ha}$

RYT

$40 \mathrm{kgN} / \mathrm{ha}$

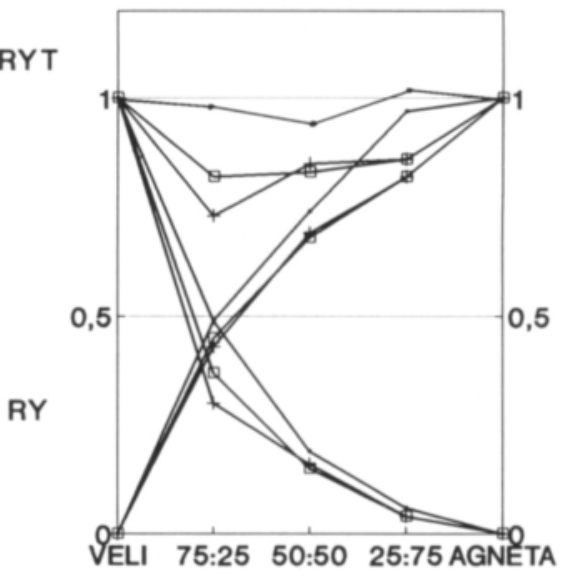

TOTAL DENSITY

$\rightarrow 200$ plants/m2

+ 500 plants/m2

- 800 plants/m2

RY

PLANTS/m2

Figure 3. The influence of density (plants $\left./ \mathrm{m}^{2}\right)$, nitrogen fertilization $(\mathrm{kg} \mathrm{N} / \mathrm{ha})$ and proportion of the components on the relative yields (RY) of Agneta barley and Veli oats, and on the relative yield totals (RYT) of the mixtures in 1984.

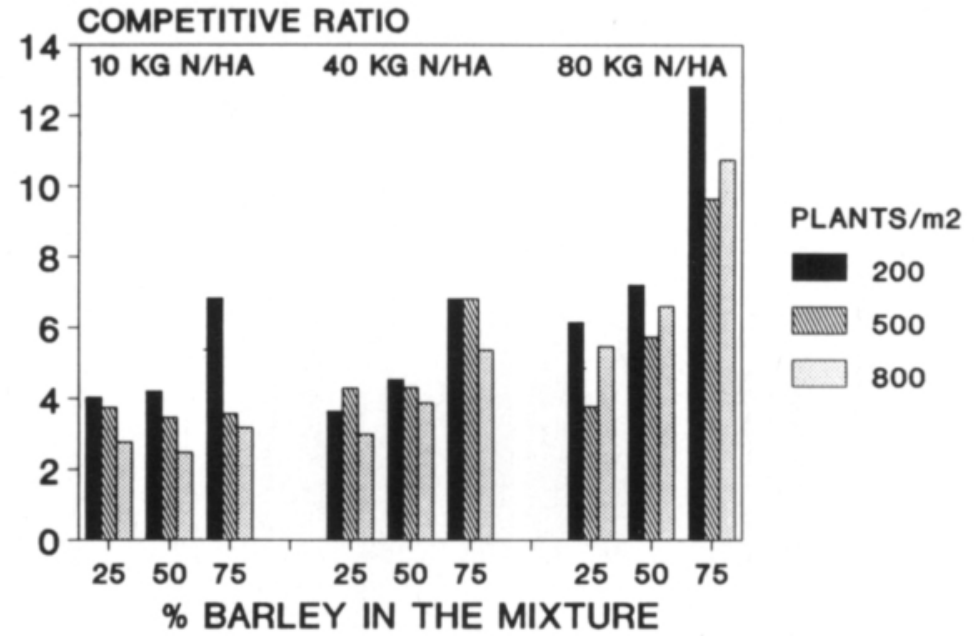

Figure 4. The influence of density (plants $\left./ \mathrm{m}^{2}\right)$, nitrogen fertilization $(\mathrm{kg} \mathrm{N} / \mathrm{ha})$ and proportion of barley on the competitive ratio (CR) of Agneta barley over Veli oats in 1984. 
petitive over oats than was Ida. In 1984, Agneta was more competitive than in the previous year. Especially Agneta barley was the most competitive at the highest level of nitrogen fertilization. In 1984, unlike the previous year, the competitive ratio of Agneta usually increased with increasing proportion of barley.

As a rule, the relative yield totals exceeded one in 1983 (Fig. 1). In 1984, the relative yield totals of both mixtures were close to or lower than one (Figs 3 and 5).

\section{Regression models}

The regression equations accounted for $90-96 \%$ of the variation in grain yield of both species $\left(\mathrm{R}^{2}=0.90-0.99\right)$ (Tables 7, 8 and 9). Only in 1984 in the mixture of Agneta barley and Veli oats were the regression coefficients of oats not statistically significant in regression equations for oats.

As a rule, the intraspecific competition of barley was more severe than the interspecific competition and vice versa for oats. Barley

Table 6. The influence of nitrogen fertilization, density and the proportion of barley (Ida) and oats (Veli) in the mixture on the grain yield $(\mathrm{kg} / \mathrm{ha})$ of the stands in 1984 . A/E is the ratio of the actual and expected yield of the mixture of 50:50. Grain yield averages within each treatment (nitrogen fertilization, density and proportions) followed by the same letter are not significantly different at the $5 \%$ level (HSD test).

\begin{tabular}{|c|c|c|c|c|c|}
\hline \multirow{2}{*}{$\begin{array}{l}\text { Proportion } \\
\text { Oats/barley }\end{array}$} & \multirow{2}{*}{$\begin{array}{c}\text { Density } \\
\text { (plants } / \mathrm{m}^{2} \text { ) }\end{array}$} & \multicolumn{4}{|c|}{ Nitrogen fertilization $(\mathrm{kgN} / \mathrm{ha})$} \\
\hline & & 10 & 40 & 80 & Average \\
\hline \multirow[t]{4}{*}{$100 / 0$} & 200 & 2588 & 2657 & 2748 & 2664 \\
\hline & 500 & 2657 & 3292 & 2769 & 2896 \\
\hline & 800 & 2853 & 2908 & 2908 & 2890 \\
\hline & Average & 2689 & 2952 & 2808 & 2816 a \\
\hline \multirow[t]{4}{*}{$75 / 25$} & 200 & 3342 & 3500 & 3473 & 3438 \\
\hline & 500 & 3469 & 3788 & 3979 & 3745 \\
\hline & 800 & 2992 & 3673 & 3993 & 3553 \\
\hline & Average & 3268 & 3654 & 3815 & $3579 \mathrm{~b}$ \\
\hline \multirow[t]{4}{*}{$50 / 50$} & 200 & 4466 & 4372 & 4075 & 4304 \\
\hline & 500 & 4028 & 4944 & 4656 & 4543 \\
\hline & 800 & 4697 & 4564 & 4795 & 4685 \\
\hline & Average & 4397 & 4627 & 4509 & $4511 \mathrm{c}$ \\
\hline \multirow[t]{4}{*}{$25 / 75$} & 200 & 4679 & 5047 & 5149 & 4958 \\
\hline & 500 & 4546 & 5459 & 5643 & 5216 \\
\hline & 800 & 5615 & 5223 & 5441 & 5426 \\
\hline & Average & 4947 & 5243 & 5411 & $5200 \mathrm{~d}$ \\
\hline \multirow[t]{4}{*}{$0 / 100$} & 200 & 5772 & 5741 & 5869 & 5794 \\
\hline & 500 & 6082 & 6155 & 6243 & 6160 \\
\hline & 800 & 5807 & 5789 & 5901 & 5832 \\
\hline & Average & 5887 & 5895 & 6004 & $5929 \mathrm{e}$ \\
\hline \multirow[t]{4}{*}{ Average } & 200 & 4169 & 4263 & 4263 & 4232 a \\
\hline & 500 & 4150 & 4728 & 4658 & 4512 a \\
\hline & 800 & 4393 & 4431 & 4608 & 4477 a \\
\hline & Average & 4238 a & 4474 a & 4509 a & 4407 \\
\hline \multirow[t]{4}{*}{$\mathrm{A} / \mathrm{E}$} & 200 & 107 & 104 & 95 & 102 \\
\hline & 500 & 92 & 105 & 103 & 100 \\
\hline & 800 & 108 & 104 & 109 & 107 \\
\hline & Average & 102 & 104 & 102 & 103 \\
\hline
\end{tabular}


$10 \mathrm{kgN} / \mathrm{ha}$

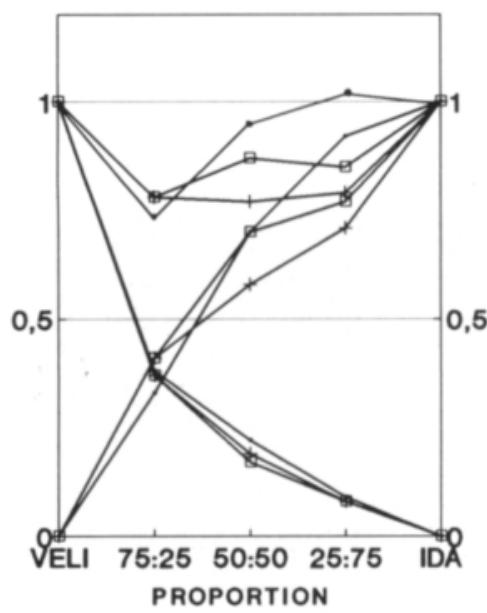

$80 \mathrm{kgN} / \mathrm{ha}$
$40 \mathrm{kgN} / \mathrm{ha}$

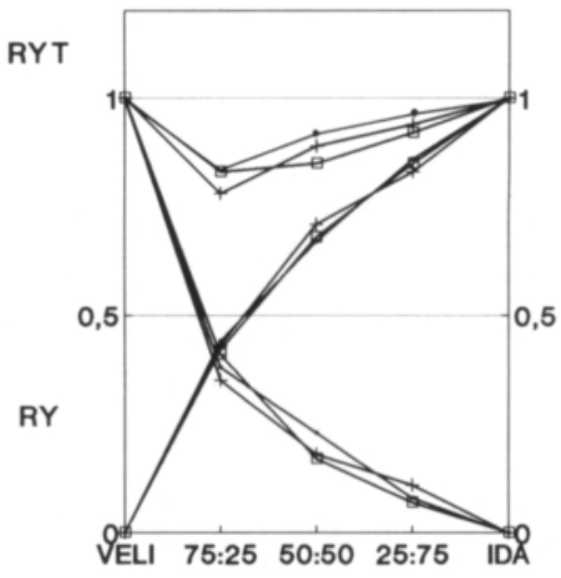

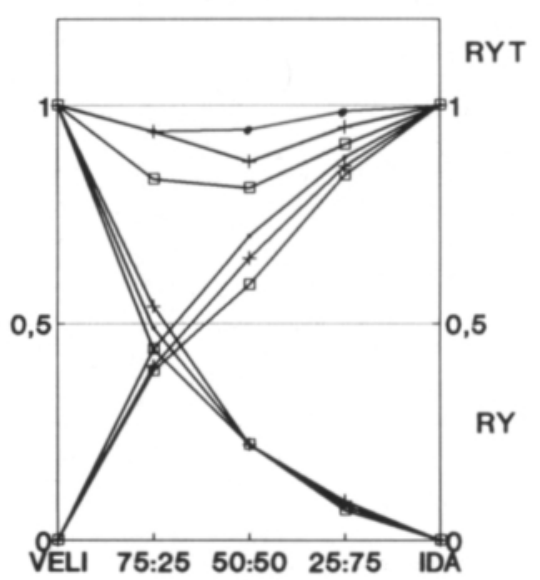

TOTAL DENSITY

$\rightarrow 200$ plants/m2

+ 500 plants $/ \mathrm{m} 2$

$\rightarrow 800$ plants/m2

RY

Figure 5. The influence of density (plants/ $\left.\mathrm{m}^{2}\right)$, nitrogen fertilization $(\mathrm{kg} \mathrm{N} / \mathrm{ha}$ ) and proportion of the components on the relative yields (RY) of Ida barley and Veli oats, and on the relative yield totals (RYT) of the mixtures in 1984.

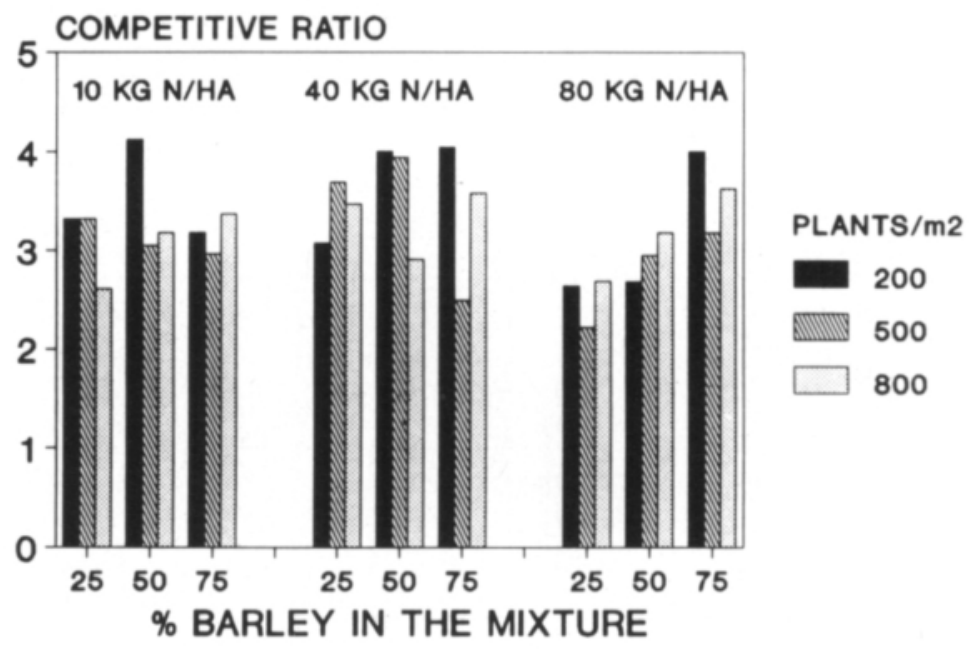

Figure 6. The influence of density $\left(\right.$ plants $\left./ \mathrm{m}^{2}\right)$, nitrogen fertilization $(\mathrm{kg} \mathrm{N} / \mathrm{ha})$ and proportion of barley on the competitive ratio (CR) of Ida-barley over Veli-oats in 1984. 
Table 7. Multispecies reciprocal yield models $(1 / \mathrm{W}=\mathrm{B} 0+\mathrm{B} 1 \mathrm{~N} 1+\mathrm{B} 2 \mathrm{~N} 2)$ for interactions between barley (Agneta) and oats (Veli) grown at three levels of nitrogen fertilization in 1983 . *

\begin{tabular}{|c|c|c|c|c|c|c|c|c|c|}
\hline $\begin{array}{l}\text { Species } \\
\text { a (b) } \\
\text { b (a) }\end{array}$ & Nitrogen & $\begin{array}{l}\mathrm{B} 0 \\
\mathrm{Ba} 0 \\
\mathrm{Bb} 0\end{array}$ & $\begin{array}{c}\text { B1 } \\
\text { Baa } \\
\text { Bbb }\end{array}$ & $\begin{array}{l}\text { B2 } \\
\text { Bab } \\
\text { Bba }\end{array}$ & $\mathbf{R}^{2}$ & $\begin{array}{c}\mathrm{RC} \\
\mathrm{Baa} / \mathrm{Bab} \\
\mathrm{Bbb} / \mathrm{Bba}\end{array}$ & $\begin{array}{c}\text { 1/RC } \\
\mathrm{Bab} / \mathrm{Baa} \\
\mathrm{Bba} / \mathrm{Bbb}\end{array}$ & NDI & $(\mathrm{Bab} \times \mathrm{Bba})^{1 / 2}$ \\
\hline $\begin{array}{l}\mathrm{Ag}(\mathrm{Ve}) \\
\mathrm{Ve}(\mathrm{Ag})\end{array}$ & $\begin{array}{l}10 \\
10\end{array}$ & $\begin{array}{r}-15.72 \\
192.59\end{array}$ & $\begin{array}{l}2.20 \\
1.63\end{array}$ & $\begin{array}{l}1.65 \\
1.36\end{array}$ & $\begin{array}{l}0.99 \\
0.99\end{array}$ & $\begin{array}{l}1.34 \\
1.19\end{array}$ & $\begin{array}{l}0.74 \\
0.83\end{array}$ & 1.61 & 1.50 \\
\hline $\begin{array}{l}\mathrm{Ag}(\mathrm{Ve}) \\
\mathrm{Ve}(\mathrm{Ag})\end{array}$ & $\begin{array}{l}40 \\
40\end{array}$ & $\begin{array}{r}5.08 \\
223.06\end{array}$ & $\begin{array}{l}1.74 \\
1.41\end{array}$ & $\begin{array}{l}1.17 \\
1.70\end{array}$ & $\begin{array}{l}0.99 \\
0.97\end{array}$ & $\begin{array}{l}1.48 \\
0.83\end{array}$ & $\begin{array}{l}0.67 \\
1.21\end{array}$ & 1.24 & 1.41 \\
\hline $\begin{array}{l}\text { Ag (Ve) } \\
\text { Ve (Ag) }\end{array}$ & $\begin{array}{l}80 \\
80\end{array}$ & $\begin{array}{r}30.21 \\
233.34\end{array}$ & $\begin{array}{l}1.56 \\
1.37\end{array}$ & $\begin{array}{l}0.68 \\
1.77\end{array}$ & $\begin{array}{l}0.99 \\
0.94\end{array}$ & $\begin{array}{l}2.29 \\
0.77\end{array}$ & $\begin{array}{l}0.44 \\
1.29\end{array}$ & 1.75 & 1.10 \\
\hline
\end{tabular}

* b-values $x 10^{-3}$. NDI (Niche differentiation index $)=(\mathrm{Bbb} / \mathrm{Bba}) /(\mathrm{Bab} / \mathrm{Baa}) .1 / \mathrm{W}$ is the reciprocal yield of an individual plant (grain yield/plant). B0 is the reciprocal of the theoretical maximum yield of an individual, B1 describes influences of intragenotypic competition, B2 describes influences of intergenotypic competition, $\mathrm{N}$ is plant density and RC predicts relative competitive ability of each genotype. $\mathrm{p}<0.001$ for $\mathrm{B} 1$ and $\mathrm{B} 2$ in each model.

Table 8. Multispecies reciprocal yield models $(1 / \mathrm{W}=\mathrm{B} 0+\mathrm{B} 1 \mathrm{~N} 1+\mathrm{B} 2 \mathrm{~N} 2)$ for interactions between barley (Agneta) and oats (Veli) grown at three levels of nitrogen fertilization in 1984.*

\begin{tabular}{|c|c|c|c|c|c|c|c|c|c|}
\hline $\begin{array}{l}\text { Species } \\
\text { a (b) } \\
\text { b (a) }\end{array}$ & Nitrogen & $\begin{array}{l}\mathrm{B} 0 \\
\mathrm{Ba} 0 \\
\mathrm{Bb} 0\end{array}$ & $\begin{array}{l}\text { B1 } \\
\text { Baa } \\
\text { Bbb }\end{array}$ & $\begin{array}{c}\text { B2 } \\
\text { Bab } \\
\text { Bba }\end{array}$ & $\mathrm{R}^{2}$ & $\begin{array}{c}\mathrm{RC} \\
\mathrm{Baa} / \mathrm{Bab} \\
\mathrm{Bbb} / \mathrm{Bba}\end{array}$ & $\begin{array}{c}\text { 1/RC } \\
\mathrm{Bab} / \mathrm{Baa} \\
\mathrm{Bba} / \mathrm{Bbb}\end{array}$ & NDI & $(\mathrm{Bab} \times \mathrm{Bba})^{1 / 2}$ \\
\hline $\begin{array}{l}\mathrm{Ag}(\mathrm{Ve}) \\
\mathrm{Ve}(\mathrm{Ag})\end{array}$ & $\begin{array}{l}10 \\
10\end{array}$ & $\begin{array}{r}19.22 \\
1635.70\end{array}$ & $\begin{array}{l}1.71 \\
1.43\end{array}$ & $\begin{array}{r}1.04 \\
11.47\end{array}$ & $\begin{array}{l}0.95 \\
0.90\end{array}$ & $\begin{array}{l}1.64 \\
0.13\end{array}$ & $\begin{array}{l}0.61 \\
8.00\end{array}$ & 0.21 & 3.45 \\
\hline $\begin{array}{l}\mathrm{Ag}(\mathrm{Ve}) \\
\mathrm{Ve}(\mathrm{Ag})\end{array}$ & $\begin{array}{l}40 \\
40\end{array}$ & $\begin{array}{r}30.31 \\
1107.66\end{array}$ & $\begin{array}{l}1.62 \\
1.51\end{array}$ & $\begin{array}{r}0.59 \\
23.37\end{array}$ & $\begin{array}{l}0.99 \\
0.93\end{array}$ & $\begin{array}{l}2.76 \\
0.06\end{array}$ & $\begin{array}{r}0.36 \\
15.63\end{array}$ & 0.18 & 3.71 \\
\hline $\begin{array}{l}\mathrm{Ag}(\mathrm{Ve}) \\
\mathrm{Ve}(\mathrm{Ag})\end{array}$ & $\begin{array}{l}80 \\
80\end{array}$ & $\begin{array}{r}37.51 \\
2050.11\end{array}$ & $\begin{array}{r}1.68 \\
-1.77\end{array}$ & $\begin{array}{r}0.50 \\
34.09\end{array}$ & $\begin{array}{l}0.99 \\
0.91\end{array}$ & $\begin{array}{l}3.34 \\
0.05\end{array}$ & $\begin{array}{r}0.30 \\
19.23\end{array}$ & 0.18 & 4.12 \\
\hline
\end{tabular}

* b-values $\times 10^{-3}$. NDI (Niche differentiation index $)=(\mathrm{Bbb} / \mathrm{Bba}) /(\mathrm{Bab} / \mathrm{Baa}) .1 / \mathrm{W}$ is the reciprocal yield of an individual plant (grain yield/plant). B0 is the reciprocal of the theoretical maximum yield of an individual, B1 describes influences of intragenotypic competition, B2 describes influences of intergenotypic competition, $\mathrm{N}$ is plant density and RC predicts relative competitive ability of each genotype. $\mathrm{p}<0.001$ for $\mathrm{B} 1$ and $\mathrm{B} 2$ in each model of barley and for B2 in each model of oats. B1 in the models of oats is not significant.

Table 9. Multispecies reciprocal yield models $(1 / \mathrm{W}=\mathrm{B} 0+\mathrm{B} 1 \mathrm{~N} 1+\mathrm{B} 2 \mathrm{~N} 2)$ for interactions between barley (Ida) and oats (Veli) grown at three levels of nitrogen fertilization in 1984.*

\begin{tabular}{|c|c|c|c|c|c|c|c|c|c|}
\hline $\begin{array}{l}\text { Species } \\
\text { a (b) } \\
\text { b (a) }\end{array}$ & Nitrogen & $\begin{array}{l}\mathrm{B} 0 \\
\mathrm{Ba} 0 \\
\mathrm{Bb} 0\end{array}$ & $\begin{array}{l}\text { B1 } \\
\text { Baa } \\
\text { Bbb }\end{array}$ & $\begin{array}{l}\text { B2 } \\
\text { Bab } \\
\text { Bba }\end{array}$ & $\mathbf{R}^{2}$ & $\begin{array}{c}\mathrm{RC} \\
\mathrm{Baa} / \mathrm{Bab} \\
\mathrm{Bbb} / \mathrm{Bba}\end{array}$ & $\begin{array}{c}\text { 1/RC } \\
\mathrm{Bab} / \mathrm{Baa} \\
\mathrm{Bba} / \mathrm{Bbb}\end{array}$ & NDI & $(\mathrm{Bab} \times \mathrm{Bba})^{1 / 2}$ \\
\hline $\begin{array}{l}\text { Id (Ve) } \\
\text { Ve (Id) }\end{array}$ & $\begin{array}{l}10 \\
10\end{array}$ & $\begin{array}{r}23.81 \\
811.43\end{array}$ & $\begin{array}{l}1.63 \\
2.85\end{array}$ & $\begin{array}{r}0.99 \\
11.71\end{array}$ & $\begin{array}{l}0.97 \\
0.96\end{array}$ & $\begin{array}{l}1.65 \\
0.24\end{array}$ & $\begin{array}{l}0.61 \\
4.11\end{array}$ & 0.42 & 3.40 \\
\hline $\begin{array}{l}\text { Id (Ve) } \\
\text { Ve (Id) }\end{array}$ & $\begin{array}{l}40 \\
40\end{array}$ & $\begin{array}{r}-4.04 \\
442.71\end{array}$ & $\begin{array}{l}1.71 \\
3.14\end{array}$ & $\begin{array}{r}0.75 \\
11.43\end{array}$ & $\begin{array}{l}0.99 \\
0.90\end{array}$ & $\begin{array}{l}2.29 \\
0.27\end{array}$ & $\begin{array}{l}0.44 \\
3.64\end{array}$ & 0.63 & 2.92 \\
\hline $\begin{array}{l}\text { Id (Ve) } \\
\text { Ve (Id) }\end{array}$ & $\begin{array}{l}80 \\
80\end{array}$ & $\begin{array}{r}34.31 \\
415.61\end{array}$ & $\begin{array}{l}1.61 \\
2.53\end{array}$ & $\begin{array}{r}0.71 \\
12.27\end{array}$ & $\begin{array}{l}0.99 \\
0.99\end{array}$ & $\begin{array}{l}2.26 \\
0.21\end{array}$ & $\begin{array}{l}0.44 \\
4.85\end{array}$ & 0.47 & 2.95 \\
\hline
\end{tabular}

* b-values $x 10^{-3}$. NDI (Niche differentiation index $)=(\mathrm{Bbb} / \mathrm{Bba}) /(\mathrm{Bab} / \mathrm{Baa}) .1 / \mathrm{W}$ is the reciprocal yield of an individual plant (grain yield/plant). B0 is the reciprocal of the theoretical maximum yield of an individual, B1 describes influences of intragenotypic competition, B2 describes influences of intergenotypic competition, $\mathrm{N}$ is plant density and RC predicts relative competitive ability of each genotype. $\mathrm{p}<0.05$ for B1 and B2 in each model. 
benefitted at the expense of oats. The exceptional case when the intraspecific competition in the mixture was stronger than interspecific competition for both species (B1/B2>1) was at the lowest level of nitrogen fertilization in 1983 (Table 7). Then both components benefitted from mixed culture. In this case the asymptotic yields of both components grown in mixture $(1 /(\mathrm{B} 1+\mathrm{B} 2))$ were higher than the asymptotic yields of both components grown in monoculture (1/B1).

Barley was a stronger competitor than oats as determined for the ratio of regression coefficients from barley $(\mathrm{RC}=\mathrm{B} 1 / \mathrm{B} 2)$. Agneta was a stronger competitor in 1984 than in 1983. In 1984, Agneta was more competitive against oats than was Ida. In most cases the relative competitive ability of barley increased with increasing nitrogen fertilization.
Only in 1983 was the overall intraspecific competition greater than the overall interspecific competition (NDI > 1) independent of nitrogen fertilization. In 1984 the competition was more severe in the mixture of Agneta and Veli than in the mixture of Ida and Veli (NDI Agneta/Veli < NDI Ida/Veli).

The square root of the product of the interspecific competition coefficients [(BabxBba) $1 / 2$ ] was less than the intraspecific competition coefficients of barley and oats only in two cases in 1983. In these situations a mixture of optimum proportions will yield more than both monocultures, i.e. a mixture will overyield.

\section{Yield components}

In 1983, the addition of nitrogen, change

Table 10. The influence of nitrogen fertilization, density and the proportion of barley (Agneta) and oats (Veli) in the mixture on the number of generative shoots per plant of Agneta barley in 1983. Shoot number averages within each treatment (nitrogen fertilization, density and proportions) followed by the same letter are not significantly different at the $5 \%$ level (HSD test). Comparison between the shoot number means of different proportions is done at different levels of density (interaction statistically significant).

\begin{tabular}{|c|c|c|c|c|c|}
\hline \multirow{2}{*}{$\begin{array}{l}\text { Proportion } \\
\text { Barley/oats }\end{array}$} & \multirow{2}{*}{$\begin{array}{c}\text { Density } \\
\text { (plants } / \mathrm{m}^{2} \text { ) }\end{array}$} & \multicolumn{4}{|c|}{ Nitrogen fertilization (kgN/ha) } \\
\hline & & 10 & 40 & 80 & Average \\
\hline \multirow[t]{4}{*}{$100 / 0$} & 200 & 1.00 & 1.28 & 1.30 & $1.19 \mathrm{a}$ \\
\hline & 400 & 0.74 & 0.83 & 0.90 & $0.82 \mathrm{a}$ \\
\hline & 600 & 0.70 & 0.75 & 0.78 & $0.74 \mathrm{a}$ \\
\hline & Average & 0.81 & 0.95 & 0.99 & $0.92 \mathrm{a}$ \\
\hline \multirow[t]{4}{*}{$75 / 25$} & 200 & 0.89 & 1.45 & 1.59 & $1.31 \mathrm{a}$ \\
\hline & 400 & 0.67 & 0.86 & 1.03 & $0.85 \mathrm{a}$ \\
\hline & 600 & 0.67 & 0.75 & 0.82 & $0.75 \mathrm{a}$ \\
\hline & Average & 0.74 & 1.02 & 1.15 & $0.97 \mathrm{ab}$ \\
\hline \multirow[t]{4}{*}{$50 / 50$} & 200 & 1.14 & 1.26 & 1.39 & $1.26 \mathrm{a}$ \\
\hline & 400 & 0.76 & 0.83 & 0.93 & $0.84 \mathrm{a}$ \\
\hline & 600 & 0.73 & 0.74 & 0.84 & $0.77 \mathrm{a}$ \\
\hline & Average & 0.88 & 0.94 & 1.05 & $0.96 \mathrm{ab}$ \\
\hline \multirow[t]{4}{*}{$25 / 75$} & 200 & 1.37 & 1.57 & 1.74 & $1.56 \mathrm{~b}$ \\
\hline & 400 & 0.67 & 1.10 & 1.02 & $0.93 \mathrm{a}$ \\
\hline & 600 & 0.71 & 0.73 & 0.82 & $0.75 \mathrm{a}$ \\
\hline & Average & 0.92 & 1.13 & 1.19 & $1.08 \mathrm{~b}$ \\
\hline \multirow[t]{4}{*}{ Average } & 200 & 1.10 & 1.39 & 1.51 & $1.33 \mathrm{a}$ \\
\hline & 400 & 0.71 & 0.91 & 0.97 & $0.86 \mathrm{~b}$ \\
\hline & 600 & 0.70 & 0.74 & 0.82 & $0.75 \mathrm{c}$ \\
\hline & Average & $0.84 \mathrm{a}$ & $1.01 \mathrm{ab}$ & $1.10 \mathrm{~b}$ & 0.98 \\
\hline
\end{tabular}


of the total density of stands or the growth in a mixture as compared with pure culture affected all the yield components (the number of generative shoots per plant, the 1000 grain weight and number of grains per head) of both species in certain extent (Tables $10-15)$.

\section{DISCUSSION}

\section{Advantages of mixtures}

The results of the present experiment suggest that overyielding may occur in the mixtures of oats and barley under certain conditions. Other studies of mixtures of barley and oats suggest that the yield of a mixture can be above that of the better component
(Salminen 1945, van Dobben 1953, Bebawi and NAYlor 1978, TAYLOR 1978, JokineN 1991a). Syme and Bremner (1968) and Fejer et al. (1982) found that mixture yields did not exceed those of the better component.

In addition to overyielding, mixtures can be advantageous over monocultures if the yield of the mixture exceeds the mid-component but are not necessarily so. For example in 1984 the actual yields of mixtures exceeded the expected in many cases, however, the results of relative yield total of a given mixture indicated no yield advantage. Thus when relative yield total did not exceed one the same yield of barley and oats might have been obtained with monocultures as with mixtures, without changing the total area of land (WILLEY 1979). At least from field experiments the relative yield total could be assessed for the proper

Table 11. The influence of nitrogen fertilization, density and the proportion of barley (Agneta) and oats (Veli) in the mixture on the number of generative shoots per plant of Veli oats in 1983. Shoot number averages within each treatment (nitrogen fertilization, density and proportions) followed by the same letter are not significantly different at the $5 \%$ level (HSD test). Comparison between the shoot number means of different proportions is done at different levels of density (interaction statistically significant).

\begin{tabular}{|c|c|c|c|c|c|}
\hline \multirow{2}{*}{$\begin{array}{l}\text { Proportion } \\
\text { Oats/Barley }\end{array}$} & \multirow{2}{*}{$\begin{array}{c}\text { Density } \\
\text { (plants } / \mathrm{m}^{2} \text { ) }\end{array}$} & \multicolumn{4}{|c|}{ Nitrogen fertilization (kgN/ha) } \\
\hline & & 10 & 40 & 80 & Average \\
\hline \multirow[t]{4}{*}{$100 / 0$} & 200 & 0.80 & 0.77 & 0.92 & $0.83 \mathrm{~b}$ \\
\hline & 400 & 0.70 & 0.70 & 0.73 & $0.71 \mathrm{a}$ \\
\hline & 600 & 0.59 & 0.60 & 0.64 & $0.61 \mathrm{a}$ \\
\hline & Average & 0.70 & 0.69 & 0.76 & $0.72 \mathrm{~b}$ \\
\hline \multirow[t]{4}{*}{$75 / 25$} & 200 & 0.85 & 0.78 & 0.87 & $0.83 \mathrm{~b}$ \\
\hline & 400 & 0.69 & 0.68 & 0.63 & 0.67 a \\
\hline & 600 & 0.60 & 0.59 & 0.55 & $0.58 \mathrm{a}$ \\
\hline & Average & 0.71 & 0.68 & 0.69 & $0.69 \mathrm{ab}$ \\
\hline \multirow[t]{4}{*}{$50 / 50$} & 200 & 0.66 & 0.67 & 0.69 & $0.67 \mathrm{a}$ \\
\hline & 400 & 0.70 & 0.68 & 0.64 & $0.67 \mathrm{a}$ \\
\hline & 600 & 0.62 & 0.66 & 0.44 & $0.57 \mathrm{a}$ \\
\hline & Average & 0.66 & 0.67 & 0.59 & $0.64 \mathrm{a}$ \\
\hline \multirow[t]{4}{*}{$25 / 75$} & 200 & 1.01 & 0.92 & 0.80 & $0.91 \mathrm{~b}$ \\
\hline & 400 & 0.64 & 0.72 & 0.67 & $0.68 \mathrm{a}$ \\
\hline & 600 & 0.66 & 0.57 & 0.52 & $0.58 \mathrm{a}$ \\
\hline & Average & 0.77 & 0.74 & 0.66 & $0.72 \mathrm{~b}$ \\
\hline \multirow[t]{4}{*}{ Average } & 200 & 0.83 & 0.79 & 0.82 & 0.81 a \\
\hline & 400 & 0.68 & 0.70 & 0.67 & $0.68 \mathrm{~b}$ \\
\hline & 600 & 0.62 & 0.61 & 0.54 & $0.59 \mathrm{~b}$ \\
\hline & Average & $0.71 \mathrm{a}$ & $0.70 \mathrm{a}$ & $0.68 \mathrm{a}$ & 0.69 \\
\hline
\end{tabular}


evaluation of the mixture advantage.

There are only a few published experimental results with barley-oats mixtures from which it is possible to calculate relative yield totals. The relative yield total of the mixture of oats and barley was close to one (1.03) as calculated by the author from the results of eight experiments conducted by SALMINEN (1945). This indicates no or a very slight yield advantage. The results calculated by de WIT (1960) indicated that in general the yield of barley or oats is proportional to the relative space occupied by these crops. The relative yield totals calculated by the author from the experiments of SYME and BREMNER (1968) varied from 0.90 to 1.15 with two out of seven values being lower than one. The calculated relative yield totals $(1.07,1.15)$ from the two experiments of FEJER et al. (1982) as well as the results of the present experiment in 1983 suggest that cropping of mixtures of barley and oats may be of benefit. However, more experiments in different environments are needed to provide support for the practical use of mixtures.

In addition to possible yield advantages there are other benefits of growing barley and oats in mixture such as prevention of lodging (de WIT 1960). The results of the present experiments in 1984 suggest that lodging may be reduced by growing mixtures. The decreased lodging of mixtures compared with monocultures may be because of shorter barley plants in mixtures (K.J. JOKINEN unpubl.). The increasing light intensity during the growth of barley plants is known at first to increase and

Table 12. The influence of nitrogen fertilization, density and the proportion of barley (Agneta) and oats (Veli) in the mixture on thousand grain weight $(\mathrm{g})$ of Agneta barley in 1983. Grain weight averages within each treatment (nitrogen fertilization, density and proportions) followed by the same letter are not significantly different at the $5 \%$ level (HSD test). Comparison between grain weight means of different proportions is done at different levels of nitrogen fertilization (interaction statistically significant).

\begin{tabular}{|c|c|c|c|c|c|}
\hline \multirow{2}{*}{$\begin{array}{l}\text { Proportion } \\
\text { Barley/Oats }\end{array}$} & \multirow{2}{*}{$\begin{array}{c}\text { Density } \\
\left.\text { (plants } / \mathrm{m}^{2}\right)\end{array}$} & \multicolumn{4}{|c|}{ Nitrogen fertilization $(\mathrm{kgN} / \mathrm{ha})$} \\
\hline & & 10 & 40 & 80 & Average \\
\hline \multirow[t]{4}{*}{$100 / 0$} & 200 & 36.3 & 35.7 & 35.4 & 35.8 \\
\hline & 400 & 33.5 & 32.4 & 32.2 & 32.7 \\
\hline & 600 & 30.9 & 30.6 & 29.7 & 30.4 \\
\hline & Average & $33.6 \mathrm{a}$ & $32.9 \mathrm{a}$ & $32.5 \mathrm{a}$ & $33.0 \mathrm{a}$ \\
\hline \multirow[t]{4}{*}{$75 / 25$} & 200 & 36.8 & 36.3 & 35.9 & 36.3 \\
\hline & 400 & 34.7 & 34.4 & 33.1 & 34.1 \\
\hline & 600 & 32.0 & 31.6 & 30.7 & 31.4 \\
\hline & Average & $34.5 \mathrm{ab}$ & $34.1 \mathrm{~b}$ & $33.3 \mathrm{a}$ & $33.9 \mathrm{~b}$ \\
\hline \multirow[t]{4}{*}{$50 / 50$} & 200 & 37.0 & 38.1 & 37.8 & 37.6 \\
\hline & 400 & 33.9 & 34.8 & 34.2 & 34.3 \\
\hline & 600 & 31.9 & 31.9 & 31.9 & 31.9 \\
\hline & Average & $34.2 \mathrm{ab}$ & $34.9 \mathrm{~b}$ & $34.6 \mathrm{~b}$ & $34.6 \mathrm{c}$ \\
\hline \multirow[t]{4}{*}{$25 / 75$} & 200 & 37.9 & 39.7 & 38.9 & 38.8 \\
\hline & 400 & 34.7 & 35.4 & 35.6 & 35.2 \\
\hline & 600 & 32.7 & 32.8 & 32.5 & 32.7 \\
\hline & Average & $35.1 \mathrm{~b}$ & $36.0 \mathrm{c}$ & $35.7 \mathrm{c}$ & $35.6 \mathrm{~d}$ \\
\hline \multirow[t]{4}{*}{ Average } & 200 & 37.0 & 37.4 & 37.0 & $37.2 \mathrm{a}$ \\
\hline & 400 & 34.2 & 34.2 & 33.8 & $34.1 \mathrm{~b}$ \\
\hline & 600 & 31.9 & 31.7 & 31.2 & $31.6 \mathrm{c}$ \\
\hline & Average & $34.3 \mathrm{a}$ & $34.5 \mathrm{a}$ & $34.0 \mathrm{a}$ & 34.3 \\
\hline
\end{tabular}


then to reduce plant height (BrigGS 1978 p.274). Thus in the monoculture of barley, plants might shade each other more than in mixed stands light being possibly a limiting factor especially at high levels of nitrogen fertilization and at high densities.

\section{Compensation}

In 1984, the dominant-suppression relationship between barley and oats was not always complete $(\mathrm{RYT}<1)$. This indicates that in mixtures barley interfered with the yield formation of damaged oats more than expected without benefitting by itself. Thus barley was not flexible enough especially at low densities. According to de Wit (1960), the ability of undamaged component to compensate depends on the time of damage. Thus the compensa- tion relates to the determination of the yield components and flexibility of the plants during the course of the development as well as the total density of the stands. One has to notice that in an extreme case the competition experiment can degenerate into a spacing experiment for one component.

\section{Competition models}

Although there were no profound discrepancies between the results of the two different approaches for analysing competitive interactions between components, the regression approach provided a more flexible framework for mixture studies than the conventional replacement analysis. The regression analysis uses a model of competition that allows the yields of both species in a binary mix-

Table 13. The influence of nitrogen fertilization, density and the proportion of barley (Agneta) and oats (Veli) in the mixture on thousand grain weight $(\mathrm{g})$ of Veli oats in 1983. Grain weight averages within each treatment (nitrogen fertilization, density and proportions) followed by the same letter are not significantly different at the 5\% level (HSD test).

\begin{tabular}{|c|c|c|c|c|c|}
\hline \multirow{2}{*}{$\begin{array}{l}\text { Proportion } \\
\text { Oats/Barley }\end{array}$} & \multirow{2}{*}{$\begin{array}{c}\text { Density } \\
\text { plants } / \mathrm{m}^{2} \text { ) }\end{array}$} & \multicolumn{4}{|c|}{ Nitrogen fertilization (kgN/ha) } \\
\hline & & 10 & 40 & 80 & Average \\
\hline \multirow[t]{4}{*}{$100 / 0$} & 200 & 31.5 & 31.5 & 30.0 & 31.0 \\
\hline & 400 & 31.4 & 32.6 & 30.9 & 31.6 \\
\hline & 600 & 31.7 & 32.2 & 31.6 & 31.8 \\
\hline & Average & 31.5 & 32.1 & 30.8 & $31.5 \mathrm{a}$ \\
\hline \multirow[t]{4}{*}{$75 / 25$} & 200 & 31.7 & 32.9 & 31.4 & 32.0 \\
\hline & 400 & 30.5 & 31.1 & 32.5 & 31.4 \\
\hline & 600 & 32.6 & 32.1 & 31.9 & 32.2 \\
\hline & Average & 31.8 & 32.0 & 31.9 & $31.9 \mathrm{ab}$ \\
\hline \multirow[t]{4}{*}{$50 / 50$} & 200 & 32.4 & 33.0 & 32.0 & 32.4 \\
\hline & 400 & 32.3 & 32.6 & 33.2 & 32.7 \\
\hline & 600 & 32.9 & 32.3 & 32.9 & 32.7 \\
\hline & Average & 32.5 & 32.6 & 32.7 & $32.6 \mathrm{c}$ \\
\hline \multirow[t]{4}{*}{$25 / 75$} & 200 & 31.4 & 32.6 & 31.2 & 31.7 \\
\hline & 400 & 31.7 & 33.2 & 32.3 & 32.4 \\
\hline & 600 & 33.6 & 32.6 & 32.5 & 32.9 \\
\hline & Average & 32.2 & 32.8 & 32.0 & $32.3 \mathrm{bc}$ \\
\hline \multirow[t]{4}{*}{ Average } & 200 & 31.7 & 32.5 & 31.2 & $31.8 \mathrm{a}$ \\
\hline & 400 & 31.5 & 32.4 & 32.2 & $32.0 \mathrm{a}$ \\
\hline & 600 & 32.7 & 32.3 & 32.2 & $32.4 \mathrm{a}$ \\
\hline & Average & $32.0 \mathrm{a}$ & $32.4 \mathrm{a}$ & $31.9 \mathrm{a}$ & 32.1 \\
\hline
\end{tabular}


ture to be estimated at any combination of frequency and density. It was also able to partition the influences of intra- and interspecific competition quantitatively.

The competitive ratio was not always constant at different proportions with the same total density indicating that competitive ratio is dependent on frequency. For example in 1983 the dominance of Agneta as determined by competitive ratio usually decreased whereas in 1984 it usually increased with increasing proportion of Agneta in the mixture. One has to note that this cannot be concluded directly from the competition indices of the regression model because the parameters in the regression model are constant. However, from the regression models it can be predicted that when the intraspecific competition is greater than interspecific competition, the increasing frequency of an aggressor will increase its rela- tive yield relatively less than the decrease in the relative yield of a subordinate. Then the competitive ratio of an aggressor will decrease as the actual values of the competitive ratio indicated. This also suggests that in the regression model the equivalences between species (which the competition coefficients estimate) need not vary with frequency although the competitive ratio changes. Thus one should note that only when intraspecific competition is equal to interspecific competition in the mixture is the competitive ratio independent of the frequency of the components in the mixture.

It is worth noting that different methods for analysing competitive relationship between species are unable to explain in detail the biological backround of the effects. Thus the yields of the components of a mixture may also be influenced by other types of inter-

Table 14. The influence of nitrogen fertilization, density and the proportion of barley (Agneta) and oats (Veli) in the mixture on the number of grains per head of Agneta barley in 1983.

\begin{tabular}{|c|c|c|c|c|c|}
\hline \multirow{2}{*}{$\begin{array}{l}\text { Proportion } \\
\text { Barley/Oats }\end{array}$} & \multirow{2}{*}{$\begin{array}{c}\text { Density } \\
\text { (plants } / \mathrm{m}^{2} \text { ) }\end{array}$} & \multicolumn{4}{|c|}{ Nitrogen fertilization $(\mathrm{kgN} / \mathrm{ha})$} \\
\hline & & 10 & 40 & 80 & Average \\
\hline \multirow[t]{4}{*}{$100 / 0$} & 200 & 59 & 61 & 63 & 61 \\
\hline & 400 & 47 & 53 & 54 & 51 \\
\hline & 600 & 35 & 43 & 45 & 41 \\
\hline & Average & 47 & 52 & 54 & 51 \\
\hline \multirow[t]{4}{*}{$75 / 25$} & 200 & 66 & 56 & 58 & 60 \\
\hline & 400 & 55 & 53 & 53 & 54 \\
\hline & 600 & 38 & 45 & 46 & 43 \\
\hline & Average & 53 & 51 & 52 & 52 \\
\hline \multirow[t]{4}{*}{$50 / 50$} & 200 & 58 & 73 & 72 & 68 \\
\hline & 400 & 56 & 63 & 67 & 62 \\
\hline & 600 & 36 & 45 & 54 & 45 \\
\hline & Average & 50 & 60 & 64 & 58 \\
\hline \multirow[t]{4}{*}{$25 / 75$} & 200 & 64 & 64 & 72 & 67 \\
\hline & 400 & 67 & 53 & 71 & 64 \\
\hline & 600 & 39 & 53 & 65 & 52 \\
\hline & Average & 57 & 57 & 69 & 61 \\
\hline \multirow[t]{4}{*}{ Average } & 200 & 62 & 64 & 66 & 64 \\
\hline & 400 & 56 & 56 & 61 & 58 \\
\hline & 600 & 37 & 47 & 53 & 46 \\
\hline & Average & 52 & 55 & 60 & 56 \\
\hline
\end{tabular}


specific interaction than competition for growth resources such as interference with pests (frit fly damage in 1984) and diseases. The models do account implicitly for this type of interaction. However, the biological interpretation when it is based on competition for resources, may be biased because of the other type of interactions as emphasized by LoudA et al.(1990).

\section{Competition and niche differentiation}

When grown in competition, barley usually had the advantage over oats as determined by competitive ratio or relative competitive ability. The results of phytomass accumulation during the early stages of development in 1984 suggest that barley might be able to claim the available space at an earlier stage as also shown by BAEUMER and de WIT (1968), and
Syme and Bremner (1968). Syme and BremNER (1968) suggested that the initial advantage in seedling size of barley was derived from larger source of reserve material in the seed. According to the results of TAYLOR (1978), barley was also a stronger competitor than oats, contributing more than proportionally to leaf area index, dry-matter production and total number of tillers of mixtures.

However, in 1983 at low level of nitrogen, the pure culture yield of oats was higher than that of barley, oats being even a better competitor than barley as determined by competitive ratio. This result may indicate that Veli oats might be better adapted to low soil fertility (low nitrogen), whereas Agneta barley might be more responsive to added nitrogen both in mixtures and in monoculture. TRENBATH (1976) suggested that where competition for light as well as nutrients occurs, nutrient

Table 15. The influence of nitrogen fertilization, density and the proportion of barley (Agneta) and oats (Veli) in the mixture on the number of grains per head of Veli oats in 1983.

\begin{tabular}{|c|c|c|c|c|c|}
\hline \multirow{2}{*}{$\begin{array}{l}\text { Proportion } \\
\text { Oats/Barley }\end{array}$} & \multirow{2}{*}{$\begin{array}{c}\text { Density } \\
\text { (plants } / \mathrm{m}^{2} \text { ) }\end{array}$} & \multicolumn{4}{|c|}{ Nitrogen fertilization $(\mathrm{kgN} / \mathrm{ha})$} \\
\hline & & 10 & 40 & 80 & Average \\
\hline \multirow[t]{4}{*}{$100 / 0$} & 200 & 78 & 90 & 79 & 82 \\
\hline & 400 & 55 & 58 & 62 & 58 \\
\hline & 600 & 46 & 46 & 49 & 47 \\
\hline & Average & 60 & 65 & 63 & 62 \\
\hline \multirow[t]{4}{*}{$75 / 25$} & 200 & 74 & 80 & 71 & 75 \\
\hline & 400 & 58 & 57 & 57 & 57 \\
\hline & 600 & 44 & 49 & 48 & 47 \\
\hline & Average & 59 & 62 & 59 & 60 \\
\hline \multirow[t]{4}{*}{$50 / 50$} & 200 & 99 & 75 & 77 & 84 \\
\hline & 400 & 54 & 52 & 51 & 52 \\
\hline & 600 & 46 & 39 & 55 & 47 \\
\hline & Average & 66 & 55 & 61 & 61 \\
\hline \multirow[t]{4}{*}{$25 / 75$} & 200 & 66 & 58 & 66 & 63 \\
\hline & 400 & 59 & 50 & 55 & 55 \\
\hline & 600 & 45 & 46 & 52 & 47 \\
\hline & Average & 57 & 51 & 58 & 55 \\
\hline \multirow[t]{4}{*}{ Average } & 200 & 79 & 76 & 73 & 76 \\
\hline & 400 & 57 & 54 & 56 & 56 \\
\hline & 600 & 45 & 45 & 51 & 47 \\
\hline & Average & 61 & 58 & 60 & 60 \\
\hline
\end{tabular}


additions will give reversals of dominance. This is because the shoot growth of species adapted to high nutrient conditions (with intense shoot competition) usually responds more to increased nutrient supplies than does that of species adapted to low nutrient conditions (with intense root competition).

It is important to note that in the 1984 study the results did not show thoroughly the effect of the nitrogen gradient on competition. This was because of the weak response of the stands to the added nitrogen possibly due to the high release of nitrogen from the soil. The yields of oats were also depressed due to insect damage (frit fly).

The results especially in 1983 demonstrated the effect of nitrogen fertilization on the structure of mixed plant community. There will be a point along the gradient, where Veli oats and Agneta barley can stably coexist by producing the same absolute yields (either number of seeds/plant or weight/plant). From theoretical considerations it follows that a necessary condition for a stable coexistence is that the species populations are regulated in different ways (BRAAKHEKKE 1980). Thus barley and oats might be able to coexist because they are not limited by the same resources (differentiation of their realized niches). This means that in mixtures intraspecific competition of both species is greater than interspecific competition which occurred at the lowest level of nitrogen fertilization in 1983. If, however, there is no such differentiation of their realized niches, or if it is precluded by the habitat (high nitrogen in 1983 and in 1984), then one competing species (in this case barley) will eliminate or exclude the other (in this case oats). Exclusion occurs when the realized niche of the superior competitor fills those parts of the inferior competitor's fundamental niche provided by the habitat, and the weak interspecific competitor lacks a realized niche when in competition with the stronger competitor (BEGON et al. 1986 p. 258-260).

Although the overall intraspecific competition is greater than the interspecific competition in mixtures (NDI > 1), it does not necessarily mean that the species can stably coexist in that environment. This is because the strong interspecific competitor will gradually outcompete the weak interspecific competitor as the regression model predicts (in 1983 high nitrogen). Thus NDI when greater than one did not always express that the realized niches of both species differ from each other. The fundamental question is whether NDI is a relevant index for evaluating niche differentiation from a terminological point of view. Only when interspecific competition for both species is less significant than intraspecific competition the species coexist $(\mathrm{B} 1 / \mathrm{B} 2>1)$, and coexisting competititors may then exhibit differentiation of realized niches.

\section{Yield components}

All the yield components of barley tended to associate positively with higher yields per plant obtained from mixtures. The higher grain weight of oats in mixtures did not always compensate for a lower number of ears per plant and lower number of grains per ear, leading usually to a lower yield per plant of oats in mixtures. The results for yield components suggest that the type of the plants (individuals of the same species or different species) and their relative amount in the neighbourhood are also significant in respect to the formation of different yield components and not only the total density. As a rule, the yield formation of the individual plant seems to be a rather complex phenomenon in different microenvironments. 


\section{References}

Baeumer, K. \& WiT, C.T. de. 1968. Competitive interference of plant species in monoculture and mixed stands. Neth. J. Agric. Sci. 16:103-122.

Bebawı, F.F. \& NaYLoR, R.E.L. 1978. Yield performance of mixtures of oats and barley. New Phytol. $81: 705-710$.

Begon, M., Harper, J.L. \& Townsend, C.R. 1986. Ecology. Individuals, Populations and Communities. 876 p. Blackwell Scientific Publications. Oxford.

BraAKheKke, W.G. 1980. On coexistence: a causal approach to diversity and stability in grassland vegetation. Agric. Res. Rep. 902.164 p. Wageningen.

Briggs, D.E. 1978. Barley. 612 p. New York.

Connolly, J. 1986. On difficulties with replacementseries methodology in mixture experiments. J. Appl. Ecol. 23:125-137.

Connolly, J. 1987. On the use of response models in mixture experiments. Oecologia 72:95-103.

DobBen, W.H. van. 1953. Proefnemingen met mengcultuur van haver en gerst in 1952. Report on interprovince trials 42 (mimeographed). Wageningen:Central Institute for Agricultural Research. (Ref. Taylor, B.R.1978)

Fejer, S.O., Fedak, G. \& Clark, R.V. 1982. Experiments with a barley-oat mixture and its components. Can. J. Pl. Sci. 62:497-500.

Firbank, L.G. \& Watkinson, A.R. 1985. On the analysis of competition within two-species mixtures of plants. J. Appl. Ecol. 22:503-517.

Firbank, L.G. \& Watkinson, A.R. 1990. On the effects of competition: From monocultures to mixtures. In: Grace,J.B. \& Tilman,D.(eds.). Perspectives on Plant Competition. p. 166-192. Academic Press, Inc. New York.

Harper, J.L. 1977. Population Biology of Plants. 892 p. Academic Press. London.

Jokinen, K.J. 1991 a. Influence of different barley varieties on competition and yield performance in barleyoats mixtures at two levels of nitrogen fertilization. J. Agric. Sci. Finl. 63:341-51.

JOKINEN, K.J. 1991 b. Yield and competition in barley variety mixtures. J. Agric. Sci. Finl. 63:287-305.

JoKINEN, K.J. 1991 c. Assessment of competition and yield advantage in addition series of barley variety mixtures. J. Agric. Sci. Finl. 63:307-20.

LoudA, S.M., Keeler, K.H. \& Holt, R.D. 1990. Herbivore influences on plant performance and competitive interactions. In: Grace,J.B. \& Tilman,D.(eds.). Perspectives on Plant Competition. p. 413-444. Academic Press, Inc. New York.

Roush, M.L., Radosevich, S.R., Wagner, R.G., MaXWell, B.D. \& Petersen, T.D. 1989. A comparison of methods for measuring effects of density and proportion in plant competition experiments. Weed Sci. $37: 268-275$.

SAlminen, M. 1945. Onko ohrakaura-sekaviljan viljeminen puollettavissa. Koetoim. ja Käyt.2:6-7.

SPITtERS, C.J.T. 1983. An alternative approach to the analysis of mixed cropping experiments. I. Estimation of competition effects. Neth. J. Agric. Sci. $31: 1-11$.

Steel, R.G.D. \& Torrie, J.H. 1980. Principles and procedures of statistics. A biometrical approach. 2nd Edition. 633 p. McGraw-Hill Kogakusha, Ltd. Tokyo.

SYME, J.R. \& BREMNER, B.M. 1968. Growth and yield of pure and mixed crops of oats and barley. J. Appl. Ecol. 5:659-674.

TAYLOR,B.R. 1978. Studies on a barley-oats mixture. J. Agric. Sci., Camb. 91:587-591.

Trenbath, B.R. 1976. Plant interactions in mixed crop communities. In: R.I.

Papendick et al. (eds.). Multiple Cropping. Am. Soc. Agron. Spec. Publ. 27:126-169. Madison.

WILLEY, R.W. 1979. Intercropping - Its importance and research needs. Part 1. Competition and yield advantages. Field Crop Abst. 32:1-10.

Willey, R.W. \& RAO, M.R. 1980. A competitive ratio for quantifying competition between intercrops. Exp. Agric. 16:117-125.

WIT, C.T. de. 1960. On competition. Versl. Landbouwk. Onderz. 66.8:1-82.

WIT, C.T. de \& BerG, J.P. van den. 1965. Competition between herbage plants. Neth. J. Agric. Sci. 13:212-221.

WRIGHT, A.J. 1981. The analysis of yield-density relationship in binary mixtures using inverse polynomials. J. Agric. Sci., Camb. 96:561-567. 


\section{SELOSTUS}

\section{Ohran ja kauran välinen kilpailu ja lajien seossato - typpilannoitus, kasvutiheys ja seossuhteet.}

\section{Kari Jokinen}

Helsingin Yliopisto, kasvinviljelytieteen laitos $00710 \mathrm{Helsinki}$

Nykyinen osoite

Kemira Oy, Espoon tutkimuskeskus, PL 44, 02271 Espoo

Kenttätutkimuksissa selvitettiin ohran ja kauran välistä kilpailua ja seosten sadontuottoa lisäyssarjakoemallin avulla (kolme koetta) kahtena kasvukautena (1983 ja 1984) kokeen typpilannoituksen mäărăn muuttuessa (10 $\mathrm{kgN} / \mathrm{ha}, 40 \mathrm{kgN} / \mathrm{ha} \mathrm{ja} 80 \mathrm{kgN} / \mathrm{ha})$. Ensimmäisenä kasvukautena seoskomponentit olivat Agneta-ohra ja Velikaura ja toisena kasvukautena edellisen yhdistelmän lisăksi oli Ida-ohran ja Veli-kauran seos.

Jyväsatoon perustuvien kilpailusuhteiden analysoinnissa kăytettiin sekă korvaussarjamallia että regressioanalyysia. Molempien mallien tulokset olivat samansuuntaisia.

Ohra oli yleensă dominoivampi kuin kaura. Kuitenkin ensimmäisenă vuonna kaura oli jokseenkin yhtă hyvă kilpailija kuin ohra kasvuston typpilannoituksen määrän ollessa matalin. Ohran dominoivuus lisääntyi kasvuston typ- pilannoituksen lisääntyessä varsinkin Agnetan ja Velin seoksissa.

Ensimmäisenä vuonna useiden seoskasvustojen jyvăsato oli tilastollisesti merkitsevăsti suurempi kuin satoisimman puhdaskasvuston jyväsato. Useissa seoksissa myös suhteellinen kokonaissato oli suurempi kuin yksi, mikä merkitsi satoetua vastaaviin puhdaskasvustoihin verrattuna. Toisena vuonna kauran kärsiessä hyönteistuhoista kumpikaan ohralajike ei kyennyt kompensoimaan, seoksen sadon ollessa pienempi kuin ohran puhdaskasvustosato. Toisena vuonna myöskäăn suhteellinen kokonaissato ei ylittănyt yhtä vaikka joidenkin seosten $(1: 1)$ sato oli suurempi kuin komponenttien keskimääräinen puhdaskasvustosato. Siten satoetu ei toteudu aina ollen riippuvainen ennalta-arvaamattomista ympäristötekijöistä. 